Division of Geological \& Geophysical Surveys

PRELIMINARY INTERPRETIVE REPORT 2001-4

\title{
PALYNOLOGY OF TERTIARY HOLITNA OUTCROPS, MCGRATH AND TALKEETNA QUADRANGLES
}

\author{
by
}

Pierre A. Zippi

May 2001

THIS REPORT HAS NOT BEEN REVIEWED FOR TECHNICAL CONTENT (EXCEPT AS NOTED IN TEXT) OR FOR CONFORMITY TO THE EDITORIAL STANDARDS OF DGGS.

Released by

STATE OF ALASKA

DEPARTMENT OF NATURAL RESOURCES

Division of Geological \& Geophysical Surveys

794 University Avenue, Suile 200

Fairbanks, Alaska 99709-3645

$\$ 2.20$ 


\section{FOREWORD}

This report was prepared by Dr. Pierre A. Zippi under contract with the Alaska Division of Geological \& Geophysical Surveys (DGGS). The data summarized here was collected as part of a one-year project to evaluate the shallow gas potential of the Tertiary Holitna basin, located in the northem Sleetmute and northwestem Lime Hills quadrangles. This report is the first in a series of reports addressing the stratigraphy and shallow gas potential of the Holitna basin. Pollen identification and quantitative abundance data were provided to Dr. Zippi by Dr. Robert Ravn, also under contract with the Alaska Division of Geological \& Geophysical Surveys.

Forthcoming reports from this project include a geophysical interpretation of aeromagnetic and gravity datasets that cover the Holitna Lowland region (including the Holitna basin; preliminary report in Spring 2001 and final report in Fall 2001) and a report summarizing the shallow gas potential of the Holitna basin (Fall 2001). A regional gravity dataset covering the Holitna Lowland region was released as Alaska Division of Geological \& Geophysical Surveys GPR 2001-1 and is available from DGGS.

David L. LePain

Project Manager

May 25, 2001 


\section{Palynology of Tertiary Holitna Outcrops McGrath and Talkeetna Quadrangles}

A palynological study commissioned by the State of Alaska, Department of Natural Resources, Division of Geological and Geophysical Surveys

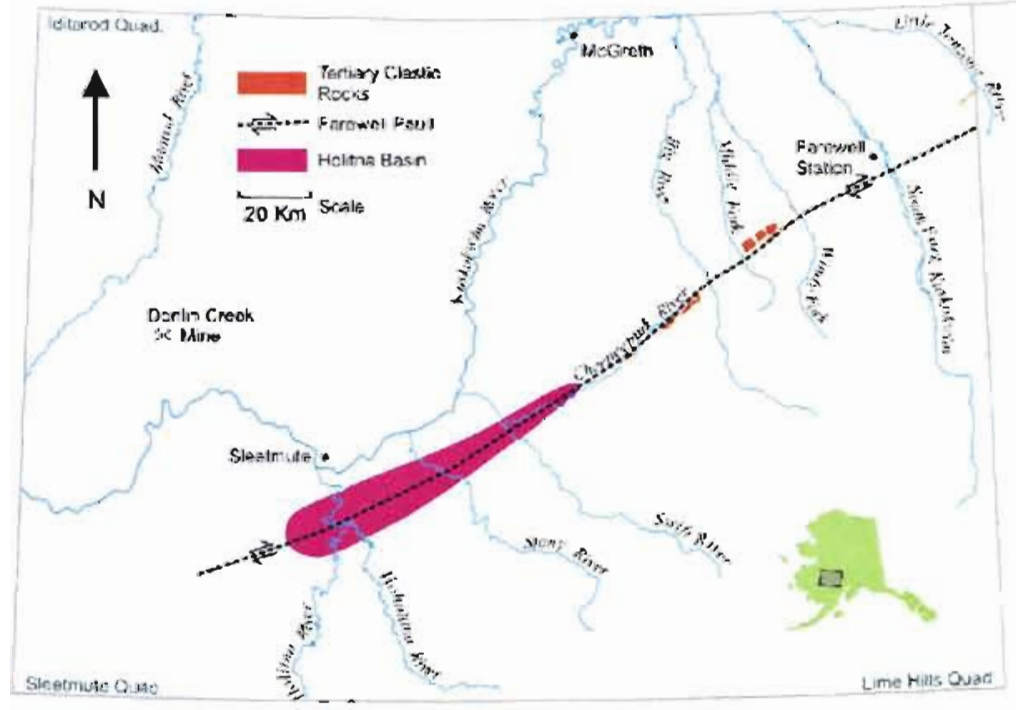

Pierre A. Zippi

Biostratigraphy.com

March 21, 2001

\section{biostratigraphy com}

7518 Twin Oaks Court Garland. Texas 75044 (972) 496-3642 paz@brostualigraphy.com www.biosiratigraphy.com 


\section{Palynology of Tertiary Holitna Outcrops}

\section{Executive summarv:}

A total of 28 samples from 5 outcrop sections were collected and processed for palynology. Seventy palynological taxa were identified. Of these, six were age diagnostic. The distributions of the age diagnostic fossils were used to determine the age limits of the outcrops. Climatic preferences of the palynofloras was used to further restrice the possible age of the outcrops.

\section{Cheeneetnuk River Section}

This section consisted of four (4) samples that yielded 23 taxa (Char 1).

Age: Middle Miocene to Late Eocene

Climate: Cold to temperate; Homerian

Depositional environment: Fluvial-paludal-lacustrine

\section{Middle Fork Kuskokwim River Section}

This section consisted of nine (9) samples that yielded 36 taxa (Chart 2).

Age: Middle Miocene to Eocene, possibly restricted to Middle Miocene

Climate: Cold to Warm temperate; Homerian

Depositional environment: Fluvial

\section{Windy Fork Kuskokwim River Section}

This section consisted of eight (8) samples that yielded 36 taxa (Chart 3).

Age: Middle Miocene to Late Eocene

Climate: Warm 10 Temperate; Homerian, ?Seldovian

Depositional environment: Fluvial

\section{Khuchaynik River Section}

This section consisted of three (3) samples that yielded only 14 taxa (Chart 4).

Age: Middle Miocene to Late Eocene

Climate: Temperate; early Homerian

Depositional environment: Fluvial

\section{Little Tonzona River Section}

This section consisted of four (4) samples that yielded 39 taxa (Chart 5).

Age: Oligocene, probably Early Oligocene

Climate: Warm to Warm temperate; pre-Angoonian, ?Goshen

Depositional environment: Fluvial 


\section{Table of contents:}

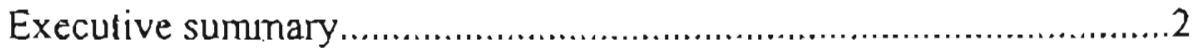

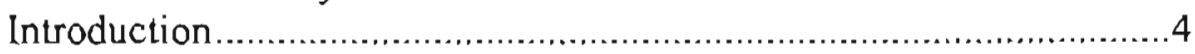

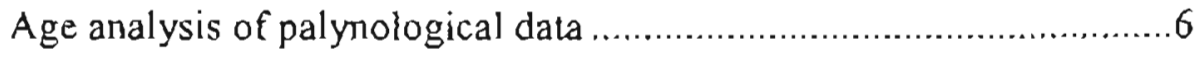

Cheeneetnuk River Section..........................................................7

Middle Fork Kuskokwim River Section ...........................................9

Windy Fork Kuskokwim River Section..................................... 11

Khuchaynik River Section ........................................................... 13

Little Tonzona River Section .................................................. 15

Macrofossil distribution ........................................................... 17

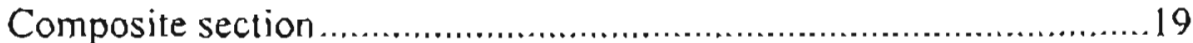

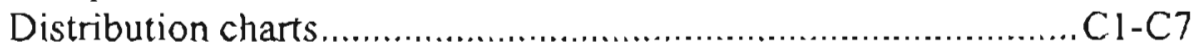




\section{Palynology of Tertiary Holitna Outcrops}

Pіете A. Zippi

Biostratigraphy.com

7518 Twin Oaks Ct.

Garland, TX 75044

\section{Introduction}

Palynological investigations were undertaken to determine a more precise age of deposition of the Tertiary outcrops in the McGrath and Talkeetna quadrangles in the Holitna River area (Figure 1, Table 1). A tolal of 28 samples from 5 outcrop sections were collected and processed for palynology. R. Ravn, Anchorage performed the palynological data acquisition. Seventy palynological taxa were identified. Additionally, Il samples were analyzed for plant macrofossil content by R. Blodgett, University of Oregon. That data was provided for this analysis and compilation.

There are no published palynological records from the Holitna River area. However, there is a great wealth of applicable published works from central Alaska and western Canada Additionally, much useful data comes from the unpublished work in the Cook Inlet Region, Alaska. Age ranges and climatic preferences for fossil taxa were researched using large fossil attribute databases maintained by Biostratigraphy.com.

In this report, the samples have been organized by field relationships. The palynological data has been organized, summarized and analyzed for infonnation related to age, climate and depositional environment. For each of the 5 sections and a composite section distribution charts, climate estimates and environmental summary charts were constructed. Plant macrofossil distributions were distilled from two discussions of analyses and a distribution chart was constructed. 


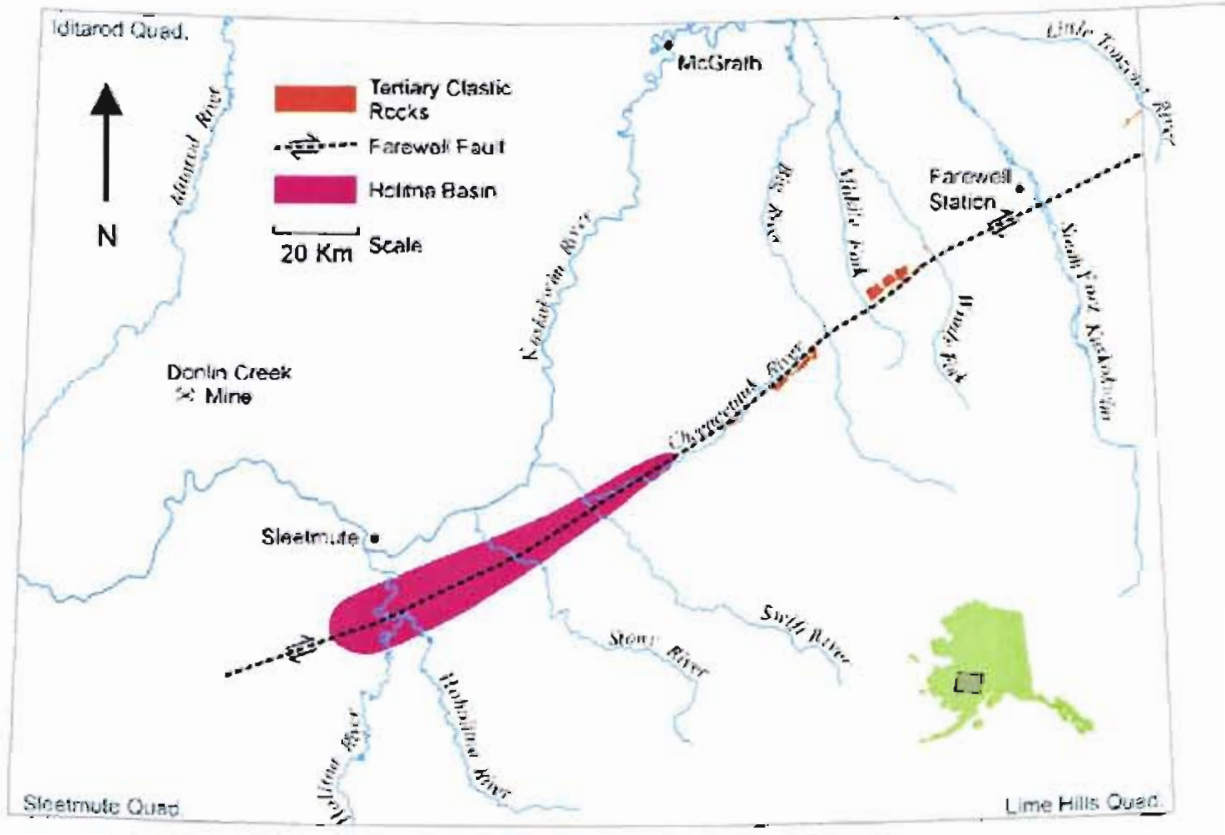

Figure 1: Location map (from D. Lepain, AK DGGS)

Location map (McGrath quad.) showing the Holitna basin and the Tertiary outcrop belt where 28 samples were collected for palynological analysis. 
Tsble 1: Sample Locstions

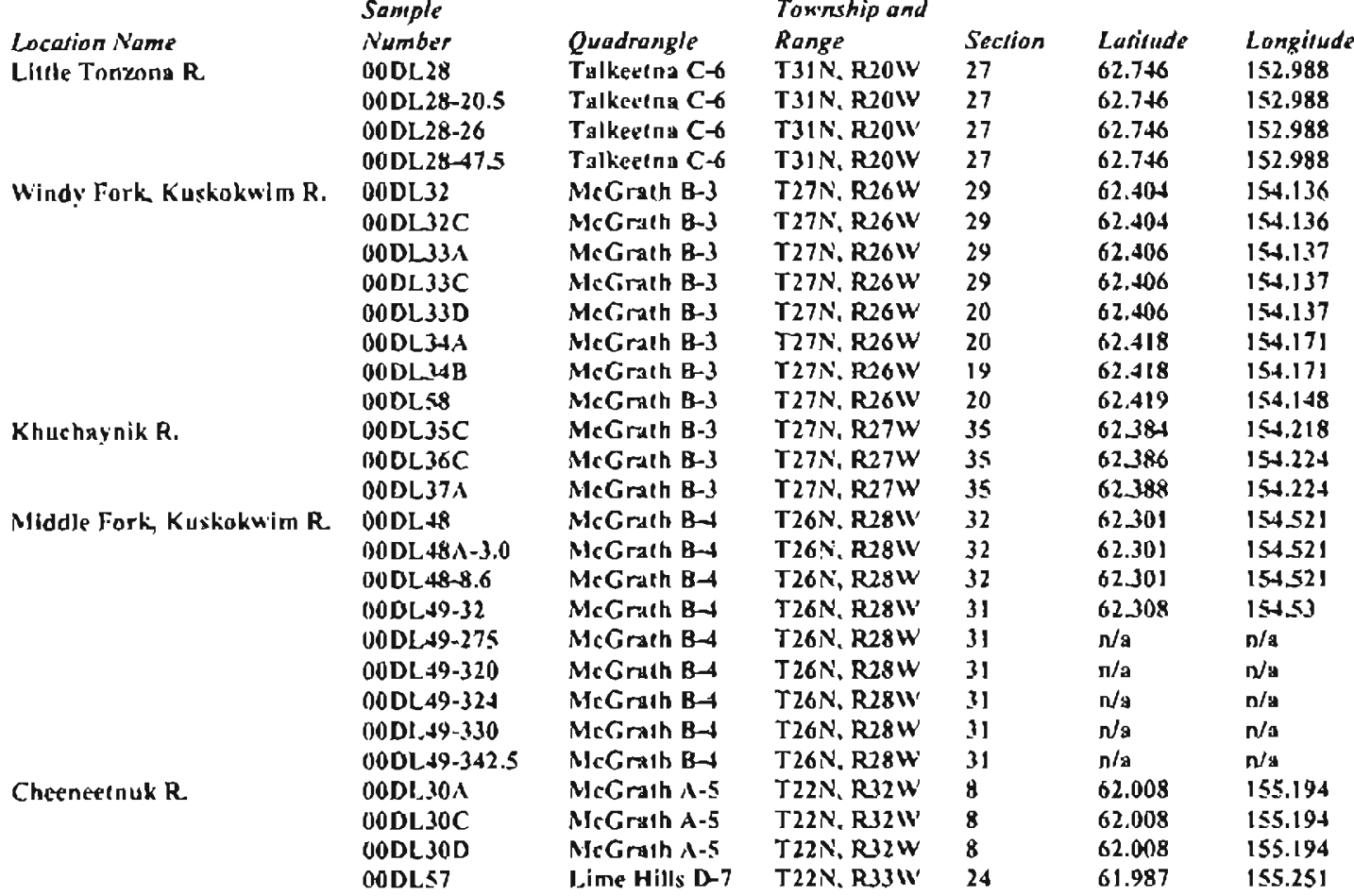




\section{Age analysis of palynological data:}

The palynology data has yielded six (6) age significant taxa from seventy palymological categories. The occurrences of these taxa are used to define the age of each outcrop section. The ranges of these taxa are discussed below.

\section{Diervilla echinata}

The age of this taxon ranges from Middle Miocene ( $11.2 \mathrm{my}$ ) to Eocene (54.8 my) based on comparison to occurrences in British Columbia, the NWT, and the Yukon. In Cook Inlet, Alaska the last appearance datum of this taxon occurs in the Late Miocene (5 my).

Both the LAD and FAD of this taxon define bounding ages of the Holitna outcrops.

\section{Tilia crassipites}

This taxon ranges from Oligocene (28.5 my) to Late Paleocene (60.9 my), worldwide. In British Columbia its range has been recorded from the Middle Miocene (11.2 my).

\section{Boisduvalia clavatites}

Age citations for this taxon are restricted to Oligocene (23.8-33.7 my) occurrences in Yukon and British Columbia, most refined estimates place it in the early Oligocene (28.5 my).

\section{Corsinipollenites oculusnoctis}

This pollen ranges from Recent to probably not older than Middle Miocene (20.5) based on comparison to Cook Inlet. Age citations from Californian localities extend back to the middle Eocene ( $37 \mathrm{my}$ ).

\section{Tsuga diversifolia}

Pollen of this species has been recorded from Paleocene to Recent. However, occurrences from high latitude localities in Eastern CIS; Sakhalin and Kamchatka Oblast, similar to the latitude of the Holitna sites, are restricted to Miocene ( $5 \mathrm{my}$ ) to Oligocene (33.7 my).

\section{Tsuga heterophylla}

Age records for the pollen of Tsuga heterophylla extend back to the Late Eocene (37my). 


\section{Results and discussion:}

\section{Cheeneetnuk River Section}

This section consisted of four (4) samples that yielded 23 taxa (see Chart 1).

\section{Age: (Middle Miocene to Late Eocene)}

The age of this outcrop section is defined as Middle Miocene or older to Late Eocene or younger by the presence of Diervilla echinata and Tsuga heterophylla.

\section{Climate: (Cold to Temperate)}

Cold and temperate taxa are about equally represented. Taxa that prefer warn climates are nearly absent in abundance terms and not dominant in diversity.

Based on age and climate this outcrop is likely equivalent to the Homerian stage.

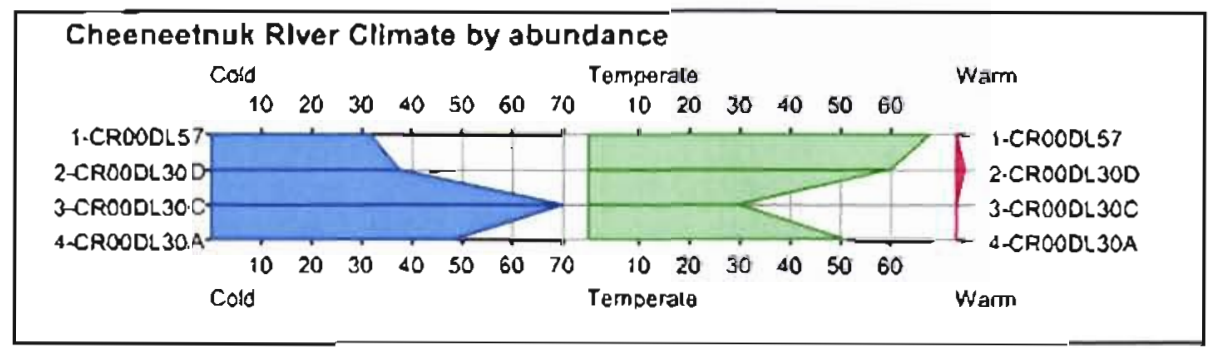

Climate indices by abundance

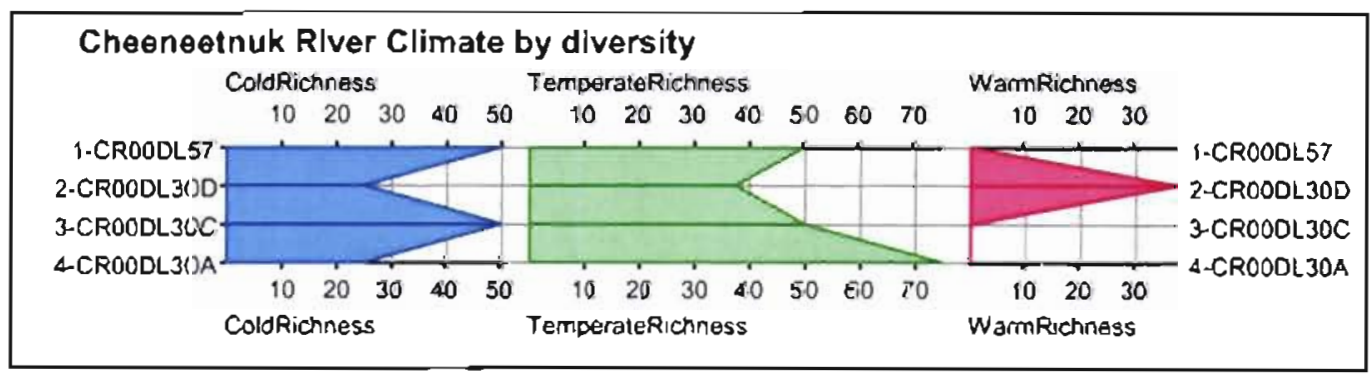

Climate indices by diversity 


\section{Depositional environment: (Fluvial-paludal-lacustrine)}

The presence of dinoflagellates and green algae along with abundant conifer pollen indicate deposition in fluvial system with standing water, such as a swamp, slough, or small lakes. The pollen flora is dominated by mixed conifer forest taxa Picea, Pinus and Tsuga with very low proportions of spores and angiosperm trees, shrubs and grasses.

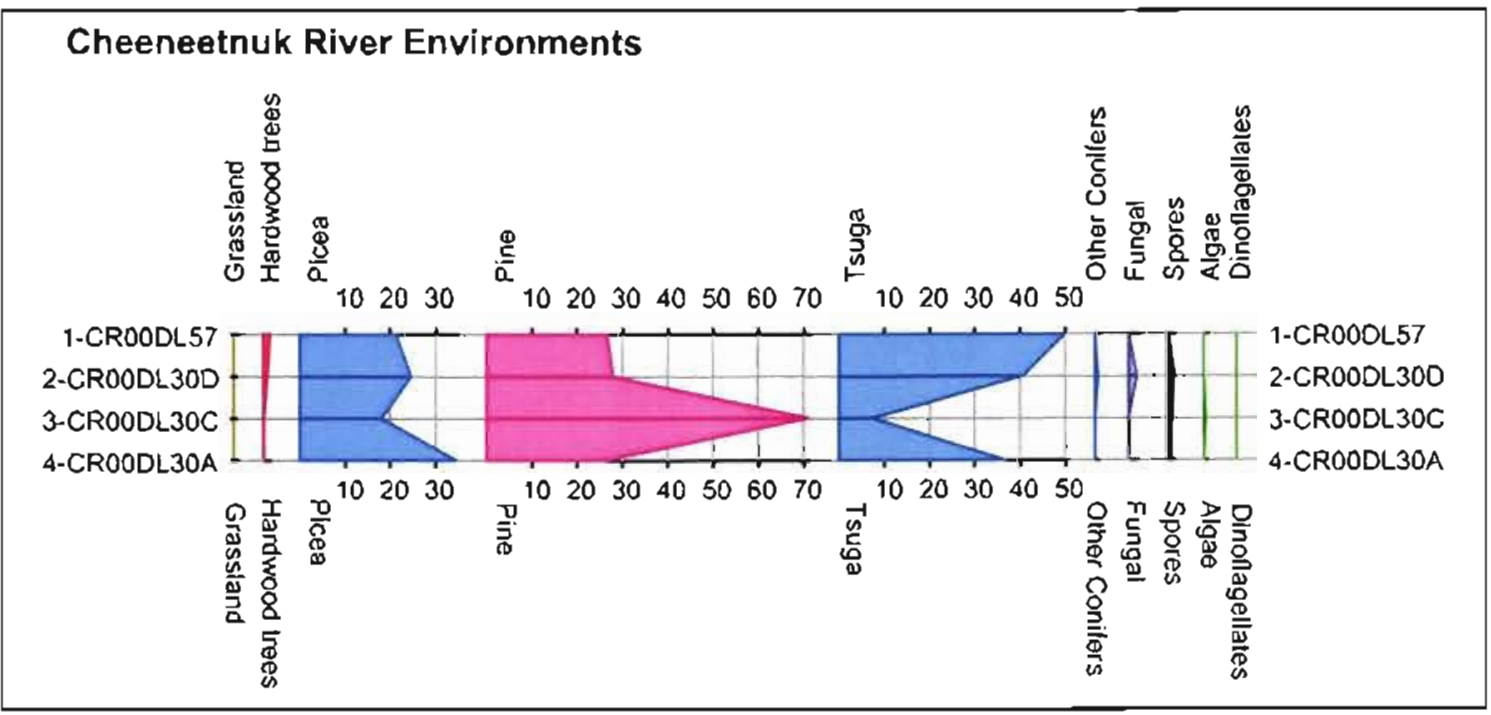

Proportions of major plant groups in the Cheeneetnuk River section. 


\section{Middle Fork Kuskokwim River Section}

This section consisted of nine (9) samples that yielded 36 taxa (see Chart 2).

\section{Age: (Middle Miocene to Eocene, possibly restricted to Middle Miocene)}

The young age limit of this outcrop section is Middle Miocene as defined by Diervilla echinata. The old age limit is certainly Late-Middle Eocene defined by the presence of Corsinipollenites oculusnoctis, Diervilla echinata and Tsuga heterophylla. The basal age limit of Corsinipollenites oculusnoctis in the Cook Inlet Region is Middle Miocene. This raises the possibility that this outcrop section may be restricted to the Middle Miocene.

\section{Climate: (Cold to Warm temperate)}

Climate response varies widely in this section. Overall this section appears to be equivalent to rocks of the Homerian Stage based on age and climate.

The wide variance in fossil content could indicate stratigraphic mixing due to faulting or it may be due to insufficient numerical characterization of the palynoflora.

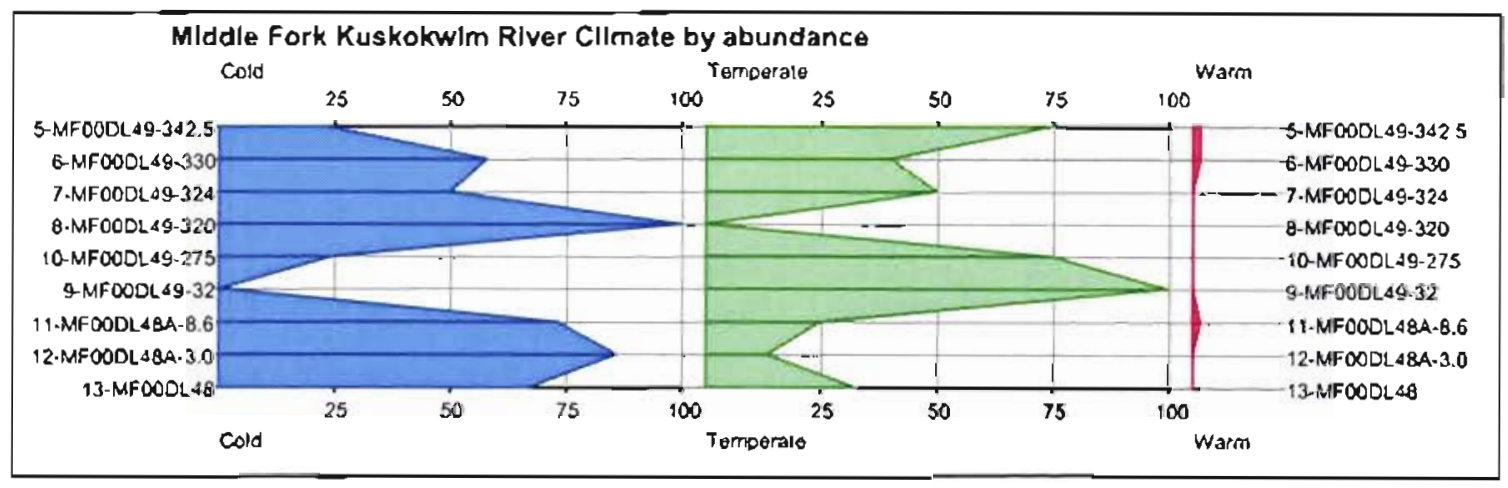

Climate indices by abundance

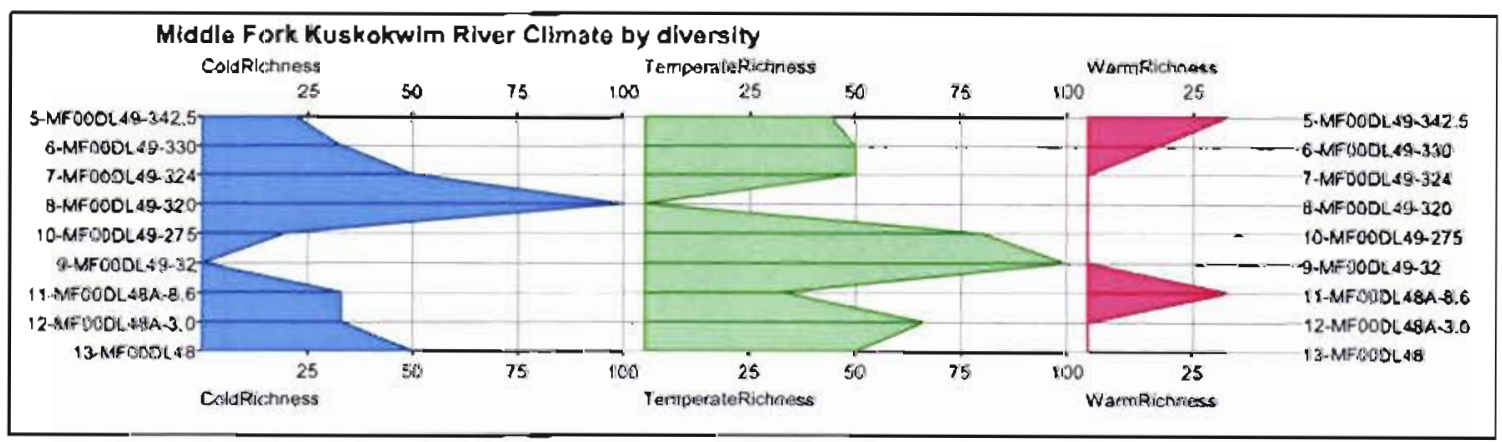

Climate indices by diversily 


\section{Depositional environment: (Fluvial)}

This section contains a heterogeneous set of samples. The presence of dinoflagellates and aquatic plants along with abundant forest tree pollen in one sample indicate deposition in forested fluvial system with standing water, such as a swamp, slough, or small lakes. The pollen flora is dominated by conifer forest taxa Picea, Pinus and Tsuga with relatively high proportions of spores and angiosperm trees and shrubs. The high diversily and abundance of fungal spores suggests a wet forest-swamp environment.

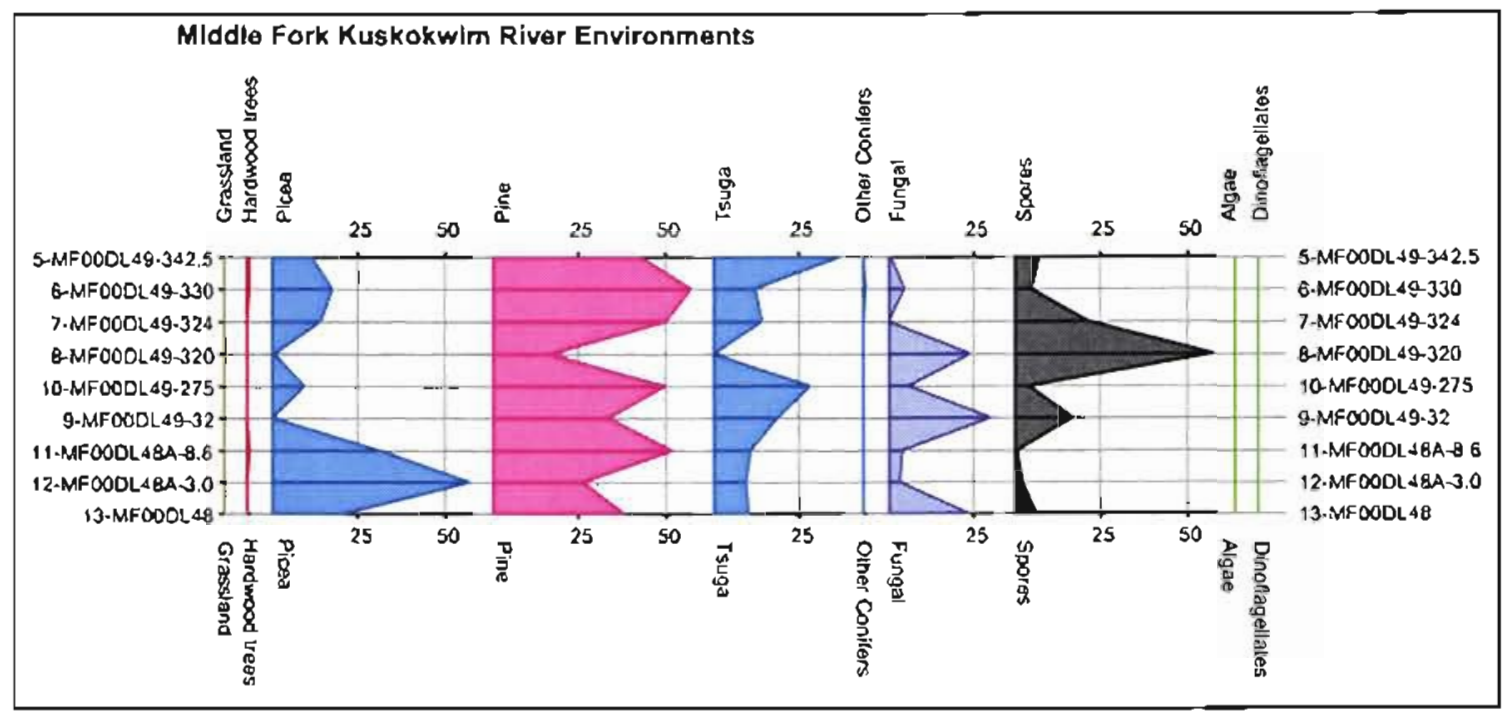

Proportions of major plant groups in the Middle Fork of the Kuskokwim River section. 


\section{Windy Fork Kuskokwim River Section}

This section consisted of eight (8) samples that yielded 36 taxa (see Chart 3).

\section{Age: (Middle Miocene to Late Eocene)}

The age of this outcrop section is restricted to the Middle Miocene (possibly Oligocene) to Late Eocene by the presence of Diervillo echinata and Tilia crassipites, and Tsuga heterophylla. Two specimens of Aquilapollenties occur in the uppermost sample. Although these specimens were recorded as reworked, this genus occurred from Late Cretaceous through Oligocene in Alaska. If these occurrences are in situ, then the age of this section would be further restricted to Oligocene to Late Eocene.

\section{Climate: (Warm to Temperate)}

The upper part of this section is warm climate while the lower portion is warm-temperate. The climate response may be affected by the lack of hardwood pollen in the lower portion. As in the Middle Fork section, the wide variance in fossil content could indicate stratigraphic mixing due to faulting or it may be due to insufficient numerical characterization of the palynoflora.

The upper samples (DL.34A, B and 58) could be equivalent to Seldovian strata while the lower samples appear to be Homerian equivalents. This would indicate a stratigraphic reversal due to faulting. If the Oligocene age were confimed in sample DL58, that sample could be equivalent to Late Angoonian or even Goshen type floras.

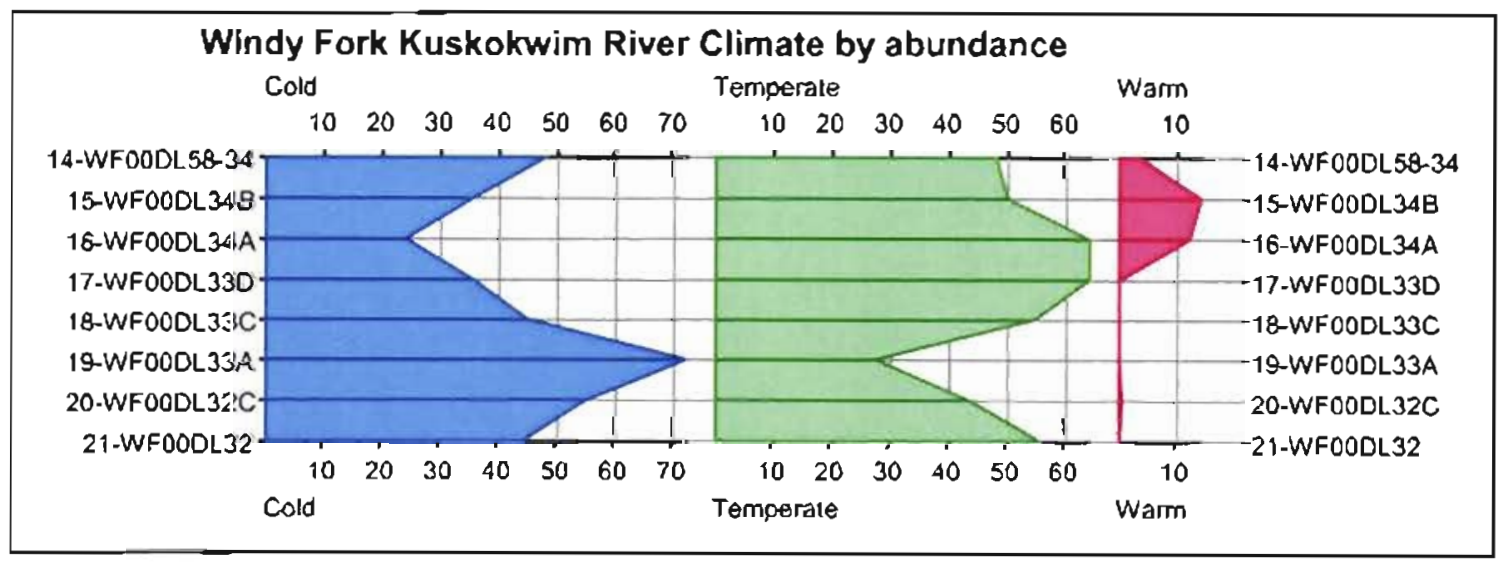

Climate indices by abundance 


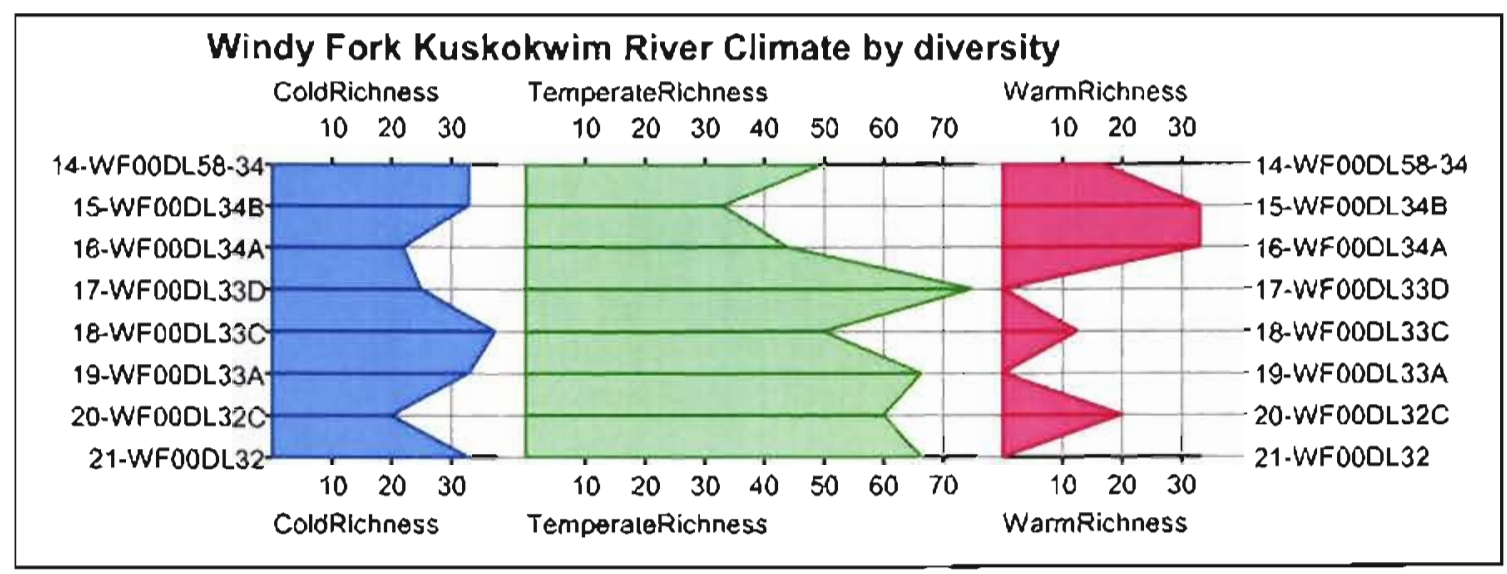

Climate indices by diversity

\section{Depositional environment: (Fluvial)}

This section also contains a heterogeneous set of samples. The presence of dinoflagellates and green algae along with abundant forest tree pollen indicate deposition in forested fluvial system with standing water, such as a swamp, slough, or small lakes. Several samples contain very high proportions of hardwoods, spores, grasses and fungal remains, typical of riparian and levee communities.

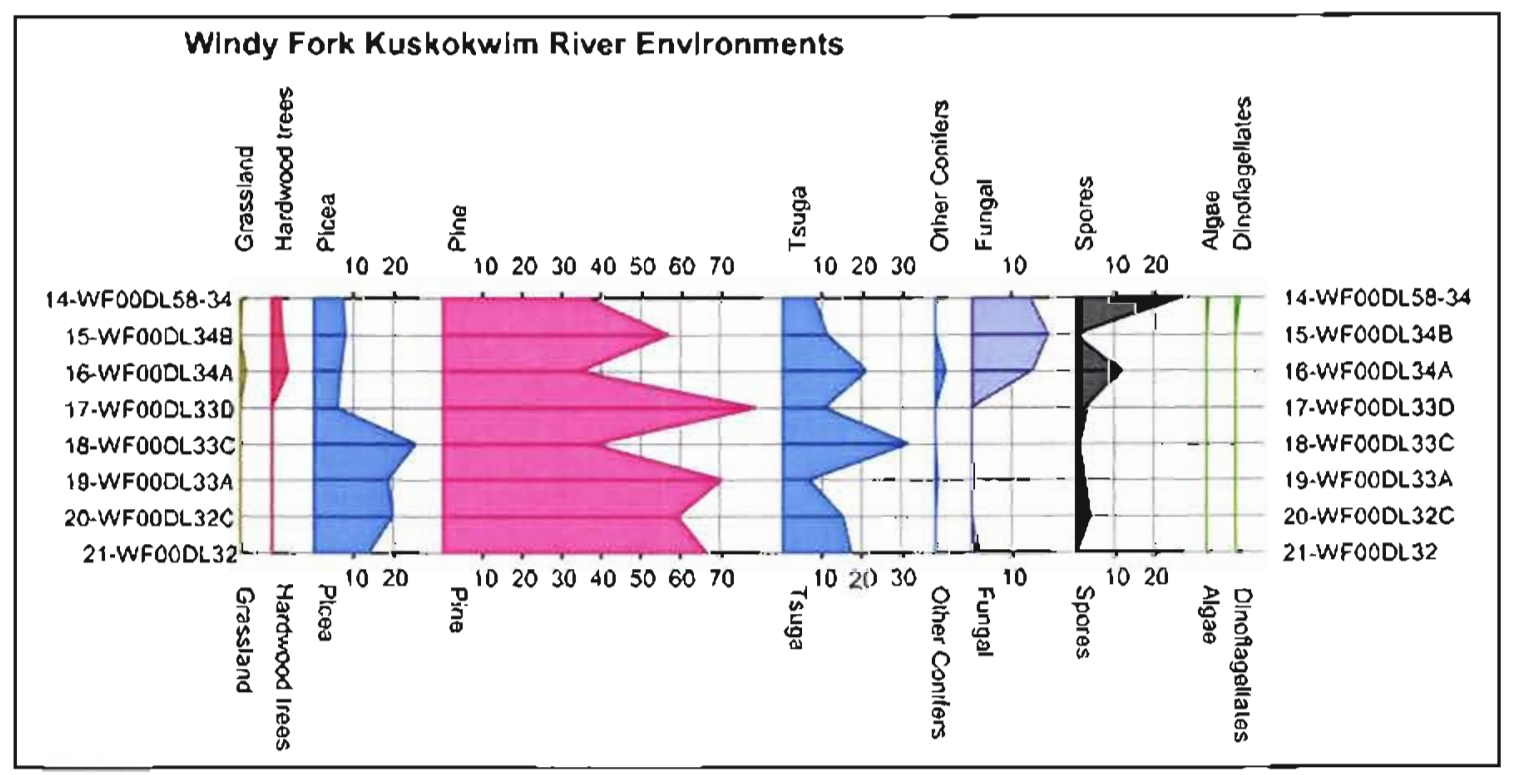

Proportions of major plant groups in the Windy Fork of the Kuskokwim River section. 


\section{Khuchaynik River Section}

This section consisted of three (3) samples that yielded only 14 taxa (see Chart 4).

\section{Age: (Middle Miocene to Late Eocene)}

The age of this outcrop section is defined as Middle Miocene or older to Late Eocene or younger by the presence of Diervilla echinata and Tstiga heterophylla.

\section{Climate: (Temperate)}

Temperate taxa are predominant. The diversily of warm and cold taxa are about equal. The relatively high proportions of temperate conifers and low presence of hardwoods suggests that this outcrop is equivalent to the early Homerian stage.

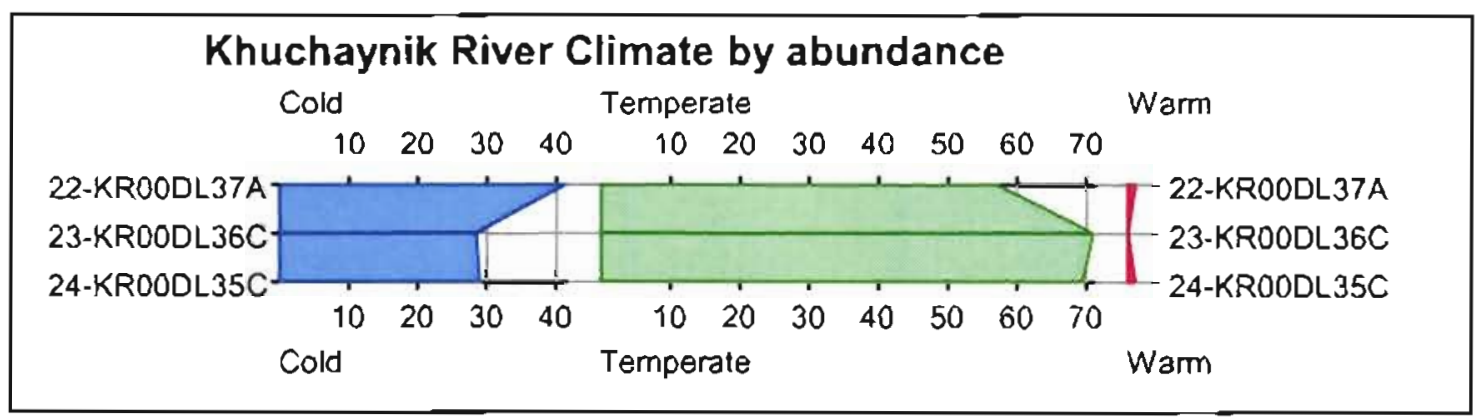

Climate indices by abundance

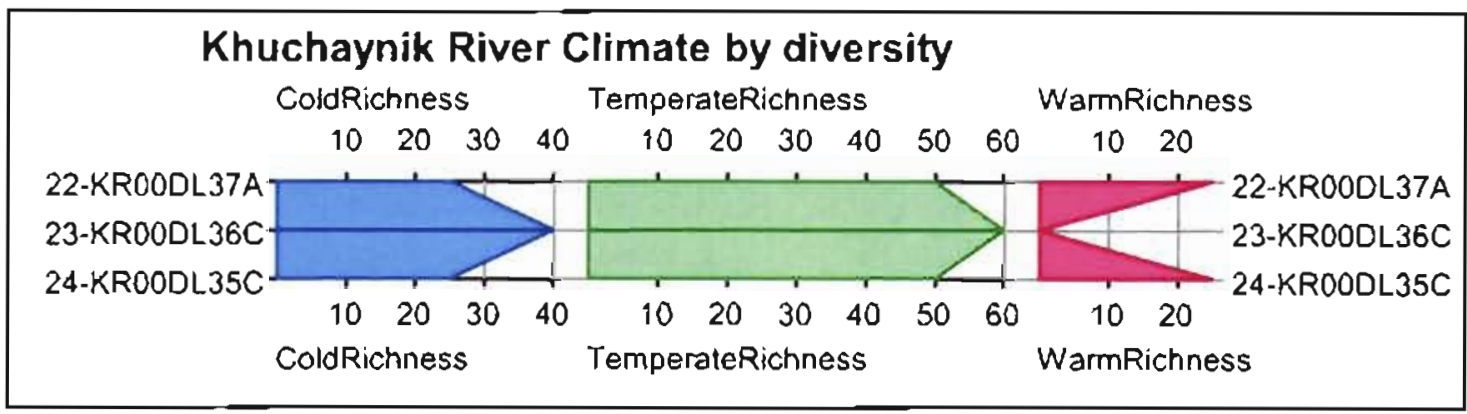

Climate indices by diversity 


\section{Depositional environment: (Fluvial)}

The pollen flora is dominated by the mixed conifer forest taxa Picea, Pinus and Tsuga with understory plants represented by shrubs and ferns. This suggesis a well drained forested fluvial system.

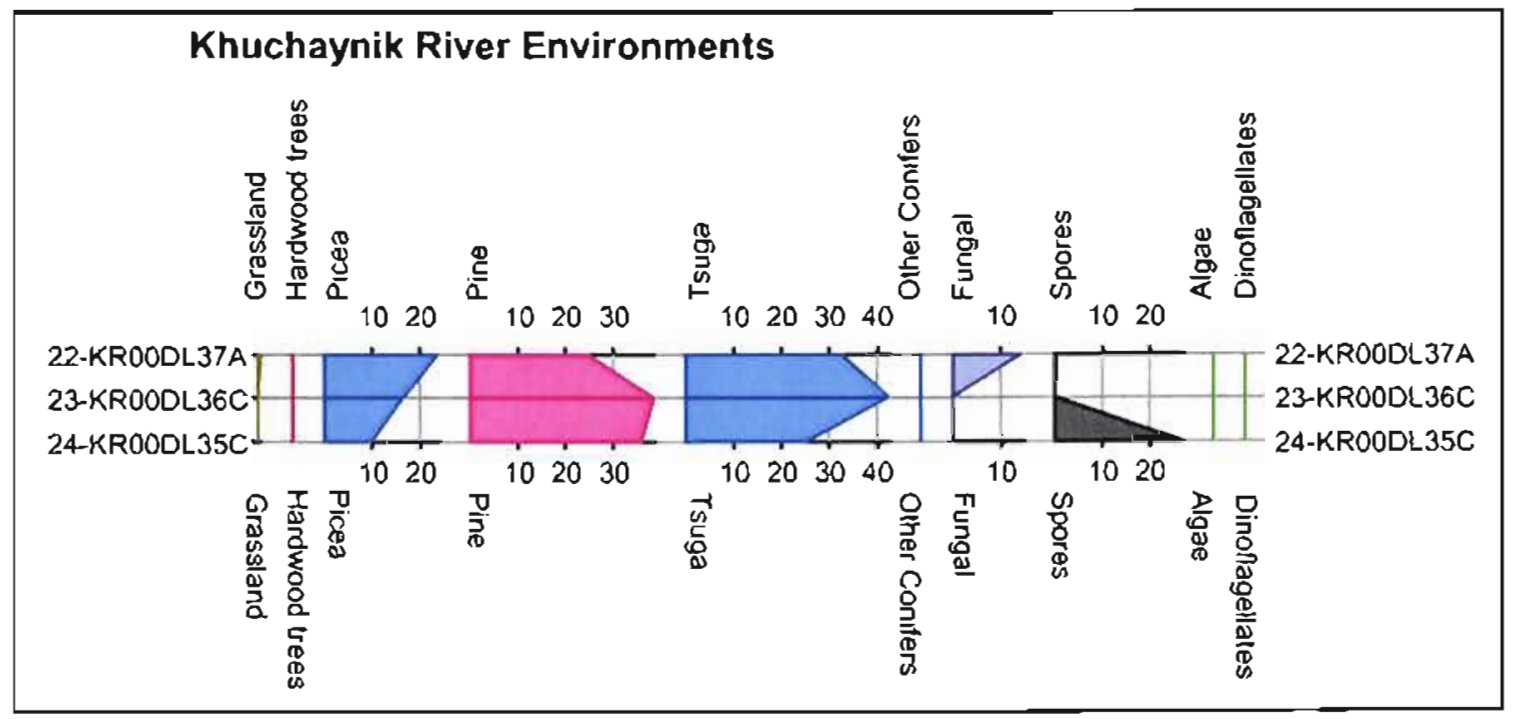

Proportions of major plant groups in the Khuchaynik River section. 


\section{Little Tonzona River Section}

This section consisted of four (4) samples that yielded 39 taxa (see Chart 5).

\section{Age: (Oligocene, probably Early Oligocene)}

The age of this outcrop section is restricted to the Oligocene (probably Early Oligocene) by the presence of Boisduvalia clovatites. The occumence of Tilia crassipites also suggests an Oligocene age (see age discussion above). This section contains 5 of the six age significant taxa recovered from the Holitna outcrops including Diervilla echinata and Tilia crassipites. Tsuga diversifolia, and Tsuga heterophylla.

\section{Climate: (Warm to Warm temperate)}

This section contains the highest representation of warm taxa and the lowest for cold taxa. Warm and remperate taxa are predominant. Angiosperm hardwood and shrub taxa are diverse and relatively abundant. Proportions of Picea and Tsuga are relatively low. The early Oligocene age and the relative warmth of this assemblage suggest that flora is equivalent to a pre-Angoonian Goshen type flora.

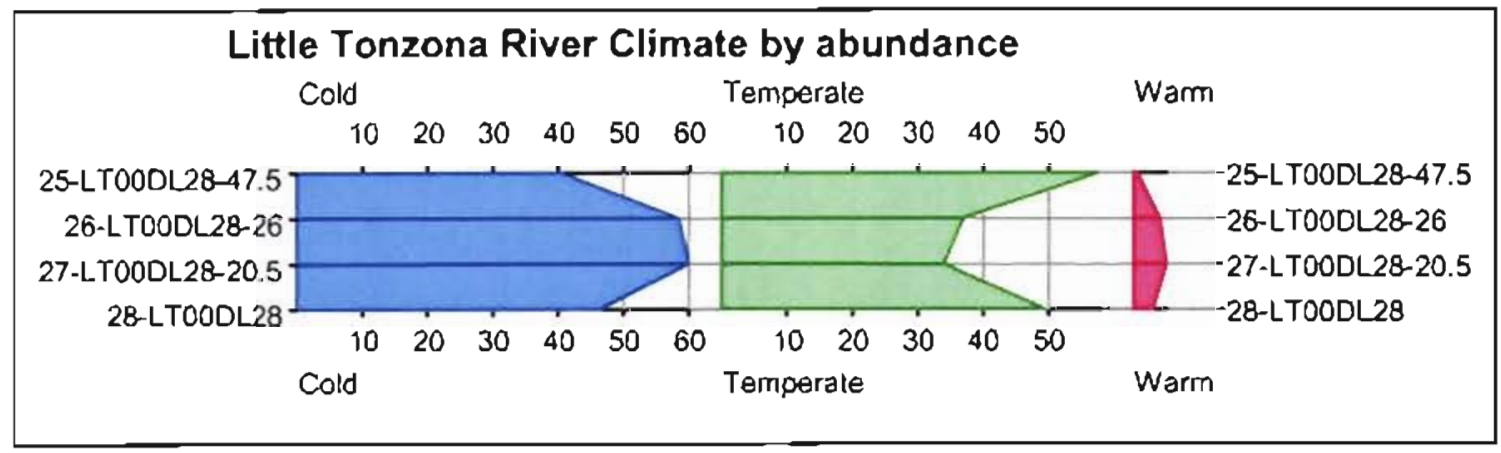

Climate indices by abundance

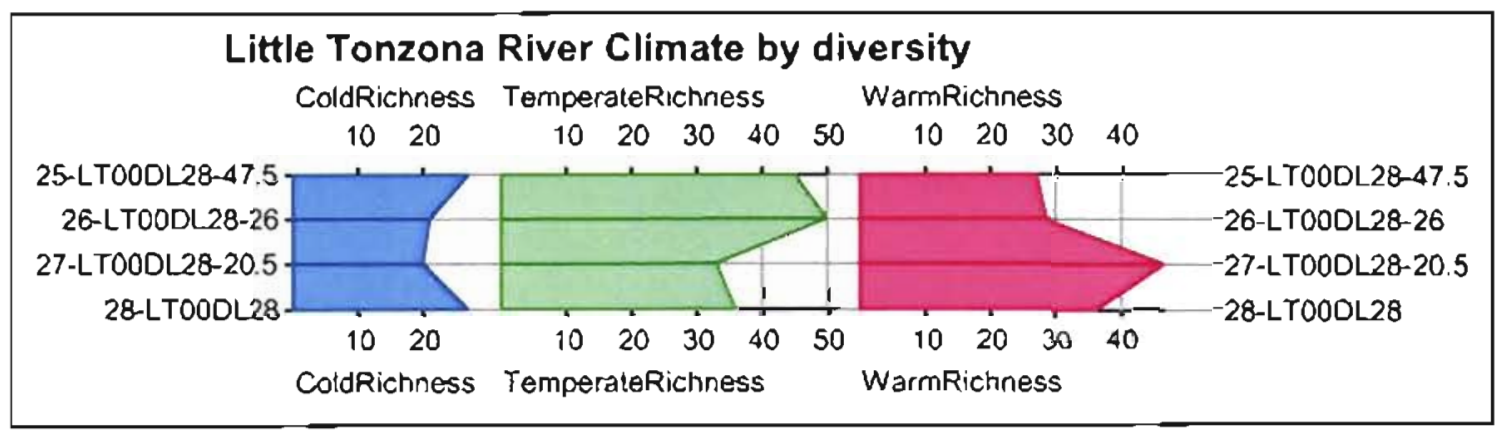

Climate indices by diversity 


\section{Depositional environment: (Fluvial)}

The presence of dinoflagellates and green algae along with abundant forest iree pollen indicate deposition in forested fluvial system with standing water, sucb as a swamp, slough, or small lakes. The pollen flora is dominated by conifer forest taxa Picea, Pinus and Tsuga with relatively high proportions of spores and angiosperm trees and shrubs.

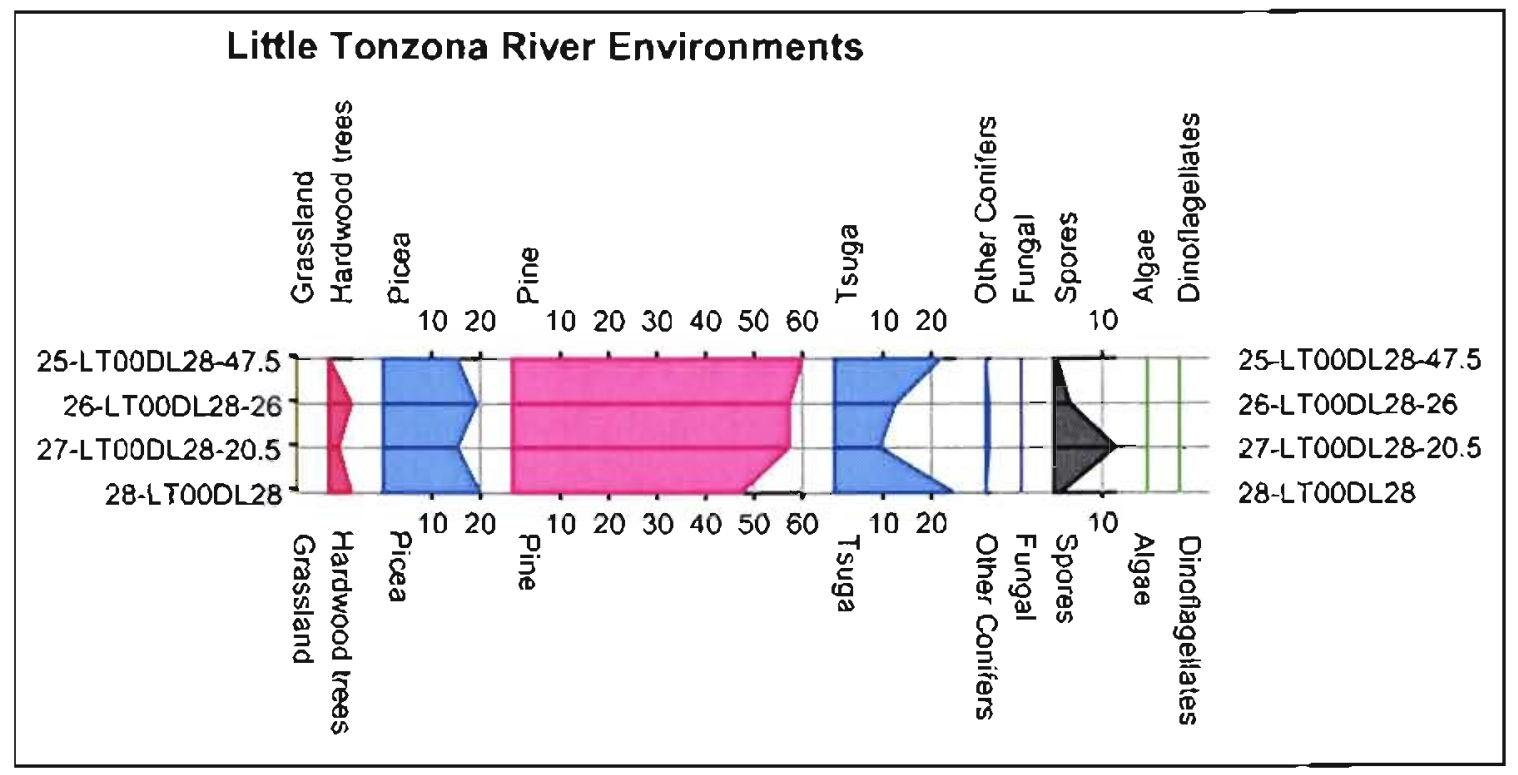

Proportions of major plant groups in the Little Tonzona River section. 


\section{Holitna Macrofossils}

Macrofossil data was made available via email transcripts from Dr. R.B. Blodgett to D. Lepain at the Alaska DGGS. For complete the distribution of macrofossils is presented here. This char (below) consists of 11 samples from three sections that yielded 15 taxa. Abundance is not indicated, only presence or absence. The macrofossil data is consistent with the palynology data. 


\section{Holitna Macrofossil Summary \\ Samole

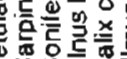 陪

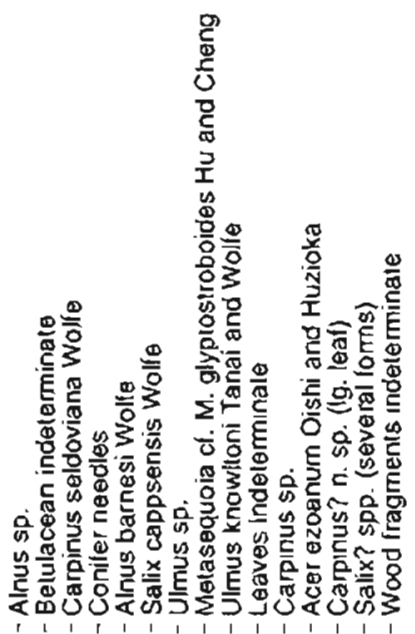

MFCODL49-273-
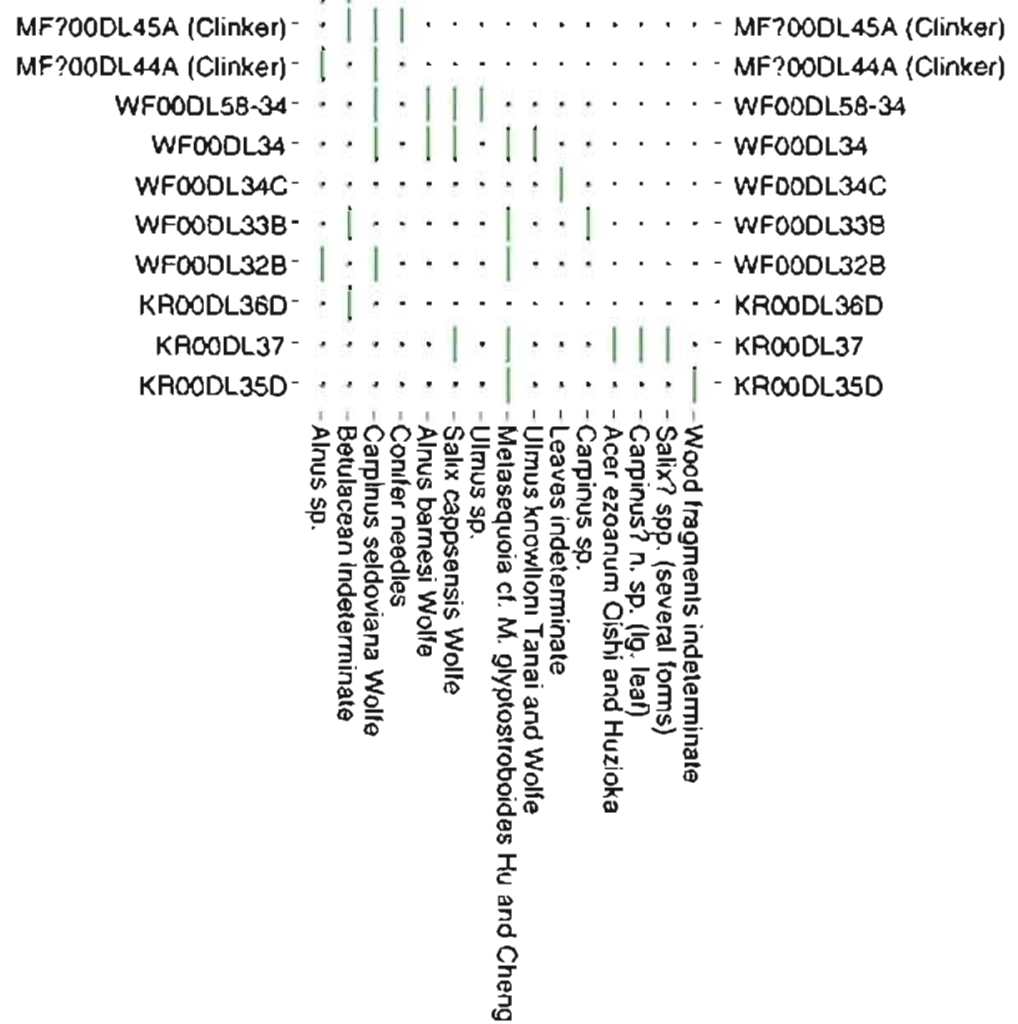

Legend

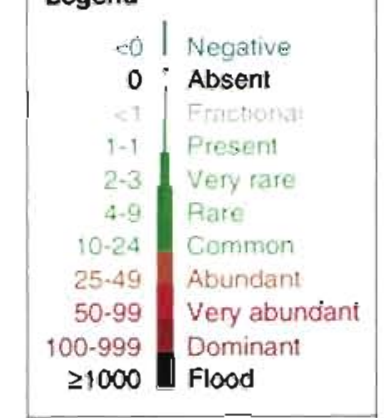

Total samples: 11

Total species: 15

Compiled with: WellPIol 2.5-PAZ Software Date plotted: 03/17/01

Compiled by Pierre Zlppi BiosIratigraphy.com From email transcriots: Dr. Roben B. Blodgett Department of Zoology Oregon State Unversity 10

Dave LePain AK DGGS

Distribution of plant macrofossils 


\section{Holitna composite section}

A composite section of the 5 outcrop sections was constructed by organizing the sections and samples by palymological age, inferred climate and field relationships (see Chart 6).

Field relationships suggest that Cheeneetnuk River section is the youngest and the Khuchaynik River section is the oldest. Lithological similarity suggests that the Windy Fork and Middle Fork sections may occupy comparable stratigraphic positions. The Little Tonzona appears to be very different from all the other sections (D. Lepain, personal communication).

Inferred age and climate from palynology place the 5 sections in the same order. The difference of the Little Tonzona River section from the others is confirmed by it being the oldest section deposited during a much warmer climate. The similarity of the Middle and Windy River sections is confirmed by the similar distribution of fossil types (Chart 7). S Windy River samples 00DL34A, 00DL34B, and 00DL58-34 yield proportions of fungal remains and conifers very similar to Middle River 00DL49-32, 00DL49-275 and 00DL49-320. 